\title{
A mouse GITRI fusion protein drives T cell activation and antitumor activity in preclinical mouse models of cancer
}

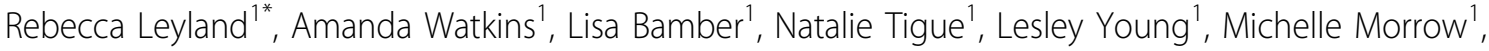 \\ Scott Hammond ${ }^{2}$, Robert Wilkinson ${ }^{1}$, Ross Stewart ${ }^{1}$
}

From 30th Annual Meeting and Associated Programs of the Society for Immunotherapy of Cancer (SITC 2015) National Harbor, MD, USA. 4-8 November 2015

GITR is a member of the TNFR superfamily of proteins and is expressed on resting regulatory $\mathrm{T}$ cells and on other T cells, and NK cells, following activation. Signals through GITR have been shown to drive increased T cell activity and reduced regulatory $\mathrm{T}$ cell function. In order to explore the potential of therapeutically targeting GITR in a cancer setting, we generated a mouse GITRL fusion protein (mGITRL FP) consisting of the extracellular domain of mGITRL linked to a structural domain and an IgG Fc domain. The antitumor activity and pharmacodynamic effects of this molecule were then explored in the colorectal syngeneic model of cancer (CT26).

Treatment of mice with mGITRL FP mediated antitumor activity that was dependent on isotype and exposure. The anti-tumour activity could be attributed at least in part to the increased activation and proliferation status of $\mathrm{CD} 8+$ and CD4+ T cells, as evidenced by increases in Ki67 expression, ICOS upregulation and increased cytokine secretion of these cells. Intratumourally we observed a significant decrease in the frequency of $\mathrm{CD} 4+\mathrm{T}$ cells (including $\mathrm{T}$ regs), but a corresponding increase in cytotoxic CD8+ $\mathrm{T}$ cells.

OX40 is another member of the TNFR superfamily, that has similar expression and functions to GITR. In order to better understand the potential differences between targeting of these two pathways, the activity and pharmacodynamic effects of the mGITRL FP were additionally compared and contrasted to those of a mOX40L FP and the observed differences will be discussed.

Medlmmune, Cambridge, UK

Full list of author information is available at the end of the article

\section{Authors' details}

${ }^{1}$ Medlmmune, Cambridge, UK. ${ }^{2}$ Medlmmune, Gaithersburg, MD, USA

Published: 4 November 2015

doi:10.1186/2051-1426-3-S2-P191

Cite this article as: Leyland et al: A mouse GITRI fusion protein drives T cell activation and antitumor activity in preclinical mouse models of cancer. Journal for ImmunoTherapy of Cancer 2015 3(Suppl 2):P191.
Submit your next manuscript to BioMed Central and take full advantage of:

- Convenient online submission

- Thorough peer review

- No space constraints or color figure charges

- Immediate publication on acceptance

- Inclusion in PubMed, CAS, Scopus and Google Scholar

- Research which is freely available for redistribution
() Biomed Central 